\title{
Cryopreservation of Immature Oocytes at Germinal Vesicle Stage. When Gamete Maturation Performance Seems to Be Most Appropriate?
}

\begin{abstract}
Реферат: Збереження фрертильності $€$ одним із пріоритетних завдань репродуктивної медицини. Однак у онкохворих пацієнтів, жінок із різними функціональними розладами яєчників можуть існувати протипоказання або не бути можливості кріоконсервування зрілих ооцитів/оваріальної тканини для збереження репродуктивного потенціалу. Тому розробка методів кріоконсервування незрілих ооцитів вважається альтернативною стратегією. У роботі оцінювали виживаність, частоту дозрівання, запліднення і розвитку ембріонів після кріоконсервування незрілих (стадія germinal vesicle (GV) - група 1) та попередньо дозрілих in vitro (IVM) (група 2) ооцитів порівняно зі зрілими in vivo ооцитами на стадії метафази II (MII) (група 3). Показник виживаності становив 97,6, 96,2 та 98,2 \% для груп 1-3 відповідно. Частота дозрівання до стадії МІІ ооцитів групи 1 була значуще меншою порівняно з групою 2 і становила 52,0 та 73,2 \% відповідно. Найбільша частота запліднення була зафіксована в групі 3, а найнижча - у групі 1. Таку саму тенденцію спостерігали щодо подальшого розвитку ембріонів для груп 1-3: частота бластуляції становила 20,0, 38,5 та 56,9 \% відповідно. Таким чином, виживаність кріоконсервованих ооцитів не залежить від їх ступеня зрілості. Однак частота запліднення та бластуляції IVM ооцитів була нижчою, ніж у зрілих in vivo гамет. Встановлено, що IVM ооцитів доцільно проводити перед кріоконсервуванням, оскільки це дозволяє отримати більш високі показники частоти дозрівання, запліднення та розвитку ембріонів in vitro.

Ключові слова: ооцити, germinal vesicle, дозрівання in vitro, кріоконсервування, вітрифікація.

Abstract: Fertility preservation is among the priorities in reproductive medicine. However, the cancer patients and women with various functional ovarian disorders, wishing to preserve future reproductive potential may have some contraindications or no possibilities to cryopreserve mature oocytes and ovarian tissue. Therefore, the development of techniques for immature oocyte cryopreservation is considered an alternative strategy. Here, we have evaluated the survival, maturation, fertilization and embryo development rates of immature oocytes (germinal vesicle (GV) stage - group 1) after cryopreservation and in vitro matured (IVM) ones (group 2) prior to cryopreservation, compared with in vivo matured metaphase-II (MII) oocytes (group 3). Survival rates were 97.6, 96.2 and $98.2 \%$ for groups $1-3$, respectively. The maturation rate of GV oocytes in group 1 was significantly lower than in group 2 and made 52.0 and $73.2 \%$, respectively. The highest fertilization rate was revealed in group 3, and the lowest one was in group 1 . The groups 1-3 showed the same tendency for further embryo development, i. e. the blastulation rates were $20.0,38.5$ and $56.9 \%$, respectively. Thus, the survival rate of cryopreserved oocytes did not depend on their maturity rate. However, the IVM oocytes displayed lower fertilization and blastulation rates, than the in vivo matured ones. It was found that oocytes IVM should be performed prior to cryopreservation, because it ensured higher rates of maturation, fertilization and embryo development in vitro.
\end{abstract}

Key words: oocyte, germinal vesicle, in vitro maturation, cryopreservation, vitrification.

Збереження фертильності - одно із пріоритетних завдань репродуктивної медицини. На сьогоднішній день успішно кріоконсервують сперматозоїди, ооцити та ембріони людини передімплантаційних стадій розвитку [17]. «Золотим» стандартом збереження фертильності людини $\epsilon$ кріоконсервування ембріонів, однак його використання може бути недоцільним у випадку, коли жінка не визначилася 3 обранцем і не має наміру використовувати донорські сперматозоїди, а також для препубертатних пацієнток

Відділ кріобіології системи репродукції, Інститут проблем кріобіології і кріомедицини НАН України, м. Харків
Fertility preservation is one of the priority tasks in reproductive medicine. To date, the human sperm, oocytes and pre-implantation embryos have been successfully cryopreserved [17]. The embryo cryopreservation is considered to be the gold standard technique for human fertility preservation, but for women without male partner and not wishing to use donated sperm, as well as for prepubertal patients, its use may be inappropriate [5]. In this regard, the oocyte cryopreservation is the best way to preserve female reproductive potential.

Department of Cryobiology of Reproductive System, Institute for Problems of Cryobiology and Cryomedicine of the National Academy of Sciences of Ukraine, Kharkiv, Ukraine

Address for correspondence:

23, Pereyaslavska str., Kharkiv, Ukraine 61016

tel.:+380 57373 4143, fax: +380 573735952

e-mail: taisiya.yur@gmail.com

Received August, 14, 2020

Accepted 20, April, 2021 
[6]. У зв’язку з цим найкращим способом збереження репродуктивного потенціалу жінки вважається кріоконсервування ооцитів. Крім того, це дозволяє оминути певні етичні та юридичні проблеми, які виникають під час кріоконсервування ембріонів. Отримання зрілих ооцитів на стадії метафази II (MII) пов'язане з розробленою Р. Едвардсом індукцією суперовуляції. Однак при гормонозалежних пухлинах проведення стимуляції яєчників неможливе через низку протипоказань, тому кріоконсервування ооцитів не застосовують для збереження фертильності таких жінок [15]. Альтернативною стратегією є кріоконсервування тканини яєчників із подальшою аутотрансплантацією або дозріванням in vitro (IVM). Незважаючи на певні досягнення у цьому напрямі (у результаті застосування цього методу у світі народилося трохи більше 130 дітей [18]) кріоконсервування оваріальної тканини на сьогодні залишається експериментальним. До того ж, аутотрансплантація кріоконсервованої тканини після одужання онкопацієнтів має певні ризики, оскільки може спричиняти метастазування [19]. Кріоконсервування окремих фолікулів могло б вирішити цю проблему, однак наразі їх дозрівання in vitro не приводило до розвитку зрілих ооцитів [11].

У природньому циклі ооцити в яєчниках знаходяться на різних стадіях розвитку. Тому для збереження фертильності жінок виникає необхідність розробки ефективних методів кріоконсервування ооцитів різних стадій зрілості, а також таких методів, які забезпечать дозрівання ооцитів до стадії МII.

Мета роботи - порівняння виживаності, частоти дозрівання, здатності до запліднення і розвитку ембріонів після кріоконсервування незрілих (стадія germinal vesicle $(\mathrm{GV})$ ) та дозрілих in vitro ооцитів людини.

\section{Матеріали та методи}

Усі маніпуляції 3 гаметами та ембріонами проводилися відповідно до звіту Головного комітету з біоетики (CDBI) про «Захист ембріона людини in vitro» CDBI-CO-GT3 (Страсбург, 2003 р.), та рішення комітету 3 біоетики Інституту проблем кріобіології та кріомедицини НАН України за інформованою згодою пацієнтів.

Дослідження проводили 3 січня 2017 по березень 2020 рр. Індукцію суперовуляції здійснювали рекомбінантним фолікулостимулюючим гормоном (GONAL-f, «Merk-Serono», Швейцарія) 3 використанням антагоністів гонадотропін-рилізинг-гормону (Цетротид, «Merk-Serono»). У якості тригера фінального дозрівання фолікулів вико-
In addition, it enables avoiding certain ethical and legal problems that may arise during embryo cryopreservation. The retrieval of metaphase II (MII) mature oocytes is associated with the procedure of superovulation induction developed by R. Edwards. However, the ovarian stimulation is not suitable in patients with hormone-dependent tumors due to a number of contraindications, thus making impossible the oocyte cryopreservation in these women for fertility preservation [14]. Cryopreservation of ovarian tissue followed by autotransplantation or in vitro maturation (IVM) is an alternative strategy. Despite certain achievements in this direction (this method application resulted in birth of just over 130 children worldwide) [18], the ovarian tissue cryopreservation has still remained experimental. In addition, the autotransplantation of cryopreserved tissue to cancer patients after recovery has certain risks of metastasis induction [19]. Cryopreservation of single follicles could solve this task, but up to now their in vitro maturation resulted in no mature oocyte development [10].

In natural cycle, the oocytes in ovaries are at different stages of development. Therefore, the designing of efficient techniques for oocyte cryopreservation at different maturity stages, as well as the methods that will ensure the oocyte maturation up to MII stage, are necessary to preserve the female fertility.

The objective herein was to compare the survival, maturation rate, ability to fertilize and embryo development after cryopreservation of immature (germinal vesicle (GV) stage) and in vitro matured human oocytes.

\section{Materials and methods}

All the manipulations with gametes and embryos were performed in accordance with the report of the Steering Committee on Bioethics (CDBI) about 'The Protection of The Human Embryo In Vitro' CDBICO-GT3 (Strasbourg, 2003), and the decision of the Bioethics Committee of the Institute for Problems of Cryobiology and Cryomedicine of the NAS of Ukraine by informed consent of patients.

The study was carried-out from January 2017 to March 2020. The superovulation was induced by administering the recombinant follicle-stimulating hormone (GONAL-f, Merk-Serono, Switzerland) with gonadotropin-releasing hormone antagonists (Cetrotide, Merk Serono). The gonadotropinreleasing hormone agonist (Decapeptyl, Ferring, Switzerland) was used for triggering final follicular maturation. Oocytes were retrieved by transvaginal ultrasound-guided (HD-11, Japon) aspiration in 35 hrs after ovulation trigger. 


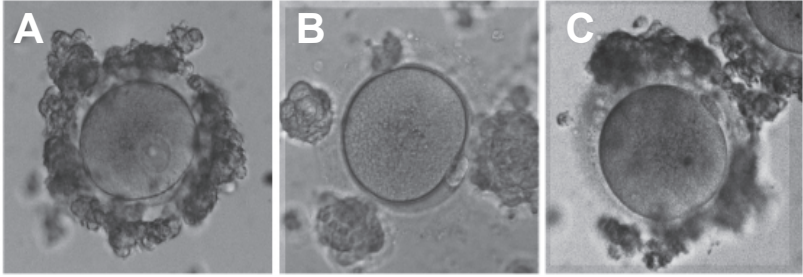

Ооцити людини різних стадій розвитку: А - гермінальний візикул; В - MII після дозрівання in vitro; C - MII після дозрівання in vivo.

Human oocytes at different development stages: A germinal vesicle, B - MII after in vitro maturation; C - MII after in vivo maturation.

ристовували агоніст гонадотропін-рилізінг-гормон (Декапептил, «Ferring», Швейцарія). Ооцити отримували шляхом трансвагінальної пункції фолікулів 3 аспірацією їх вмісту під контролем УЗД (HD-11, «Рhilips», Японія) через 35 годин після введення тригера овуляції.

Ооцити на стадії GV $(n=136)$ отримували у жінок $(n=45)$, середній вік яких становив $(32 \pm 4,6)$ років. Незрілі ооцити рандомізовано розподіляли на групи: 1 - IVM ооцитів після кріоконсервування; 2 - IVM ооцитів перед кріоконсервуванням. Контрольну групу 3 склали кріоконсервовані зрілі in vivo ооцити $(n=57)$ (рисунок). Середній вік пацієнток $(n=7)$ групи 3 складав $(33 \pm 3,5)$ років.

Ооцити кріоконсервували за допомогою кріотоп-методу [9]. Для цього після аспірації фолікулів ооцит-корона-кумулюсні комплекси відокремлювали від навкружних клітин кумулюсу i гранульози шляхом їх занурення на 30 с у $80 \mathrm{MO} /$ мл розчин гіалуронідази («Sydney IVF Hyaluronidase», «Cook Medical», США) 3 подальшим піпетуванням до повної денудації. Ооцити переносили в середовище «Global total» («Cooper Surgical Fertility Companies», США) на 2-3 години при $5 \% \mathrm{CO}_{2}$ та $37^{\circ} \mathrm{C}$. Ооцити еквілібрували в розчині, який містив 7,5\% етиленгліколю (ЕГ) («Sigma», США) та 7,5\% диметилсульфоксиду (ДМСО) («Sigma») за температури $20^{\circ} \mathrm{C}$ протягом 15 хв, після чого їх переносили на 1 хв у вітрифікаційний розчин $(15 \% \mathrm{EГ}, 15 \%$ ДМСО та 0,5 М сахарози), розміщували на носії «Cryotec» («Cryo Tech Lab Inc.», Японія) у мінімальному об'ємі рідини й одразу занурювали в рідкий азот.

Зразки відігрівали у $1,0 \mathrm{M}$ розчині сахарози («Sigma») при $37^{\circ} \mathrm{C}$ протягом 1 хв, потім ооцити переносили у розчини сахарози з концентрацією 0,5; 0,25 та 0 М. Ооцити культивували в стандарних умовах $\mathrm{CO}_{2}$-інкубатора («Hera Cell», Hiмеччина ) в середовищі «Global total».

Жіночі гамети на стадії GV дозрівали in vitro у середовищі «Global total» із додаванням ін-
The GV oocytes $(n=136)$ were retrieved in women $(n=45)$, whose mean age was $(32 \pm 4.6)$ years. Immature oocytes were randomly divided into the following groups: the group 1 comprised the IVM oocytes after cryopreservation; the group 2 included the IVM oocytes prior to cryopreservation. The cryopreserved in vivo matured oocytes $(n=57)$ were in the control group 3 (Figure). The mean age of patients $(n=7)$ in group 3 was $(33 \pm 3.5)$ years.

The oocytes were cryopreserved by the Cryotope method [8]. For this purpose, after follicle aspiration, the oocyte-corona-cumulus complexes were removed from the surrounding cumulus and granulosa cells by immersing them into $80 \mathrm{IU} / \mathrm{ml}$ hyaluronidase solution (Sydney IVF Hyaluronidase, CookMedical, USA) for $30 \mathrm{~s}$, followed by pipetting up to a complete denudation. The oocytes were transferred into the Global total medium (Cooper Surgical Fertility Companies, USA) for $2-3$ hrs at $5 \% \mathrm{CO}_{2}$ and $37^{\circ} \mathrm{C}$. They were then equilibrated in the solution, containing $7.5 \%$ ethylene glycol (EG) (Sigma, USA) and $7.5 \%$ dimethyl sulfoxide (DMSO) (Sigma, USA) at $20^{\circ} \mathrm{C}$ for $15 \mathrm{~min}$, followed by their transfer into vitrification solution (15\% EG, $15 \%$ DMSO and $0.5 \mathrm{M}$ sucrose) for $1 \mathrm{~min}$, and then placed on Cryotec carrier (Cryo Tech Lab Inc., Japan) in a minimum volume of liquid and immediately immersed into liquid nitrogen.

Samples were warmed in $1.0 \mathrm{M}$ sucrose solution (Sigma, USA) at $37^{\circ} \mathrm{C}$ for $1 \mathrm{~min}$, then transferred into sucrose solutions with $0.5 ; 0.25$ and $0 \mathrm{M}$ concentrations. Oocytes were cultured under standard conditions of $\mathrm{CO}_{2}$ incubator (Hera Cell, Germany) in Global total medium.

The GV oocytes were in vitro matured in Global total medium supplemented with insulinlike growth factor-I (Thermo Fisher Scientific, USA) in the presence of cumulus cells for 24-36 hrs. The extrusion of the first polar body indicated the oocyte maturation to MII stage. Fertilization was performed in Global total for fertilization medium (Cooper Surgical Fertility Companies, USA) by intracytoplasmic sperm injection (ICSI) into oocyte. Fertilization rate was assessed in 16-20 hrs after ICSI by presented in oocyte ooplasm two pronuclei and the extrusion of two polar bodies. The formed zygotes were transferred into $0.8 \mathrm{ml}$ Global total medium and cultured for 5 days at $5 \% \mathrm{CO}_{2}$ and $37^{\circ} \mathrm{C}$.

The data obtained were statistically processed using Statistica 8.0 software (StatSoft, USA). The groups were compared by the rates of survival, maturation, fertilization and embryo development in vitro using the $\chi_{2}$-tests. The differences were considered significant at $p<0.05$. 
суліноподібного фактора росту-I («Thermo Fisher Scientific», США) у присутності клітин кумулюсу протягом 24-36 годин. Екструзія першого полярного тіла свідчила про дозрівання ооциту до стадії MII. Запліднення здійснювали в середовищі «Global total for fertilization» («Cooper Surgical Fertility Companies», США) шляхом інтрацитоплазматичного введенння спермія (ICSI) в ооцит. Частоту фертилізації оцінювали через 16-20 годин після ICSI за наявністю в ооплазмі ооциту двох пронуклеусів та екструзії двох полярних тіл. Утворені зиготи переносили у 0,8 мл культурального середовища «Global total» та культивували протягом 5 діб при $5 \% \mathrm{CO}_{2}$ та $37^{\circ} \mathrm{C}$.

Статистичний аналіз даних проводили за допомогою програмного забезпечення «Statistica 8.0» («StatSoft», CША). Для порівняння груп за частотою виживання, дозрівання, запліднення і темпами розвитку ембріонів in vitro використовували $\chi_{2}$-тест. Відмінності вважали значущими при $p<0,05$.

\section{Результати та обговорення}

Після кріоконсервування показники виживаності для груп 1-3 становили 97,6, 96,2 та 98,2\% відповідно (таблиця). Ооцити груп 1 та 2 характеризувалися якісними морфологічними показниками: однорідною та прозорою цитоплазмою, цілісною Zona pellucida (ZP). Проте частота дозрівання ооцитів групи 1 була значуще меншою порівняно 3 групою 2 і становила 52,0 та 73,2 \% відповідно.

Частота запліднення була найбільшою у групі 3, а найнижчою - у групі 2. Спостерігання за подальшим розвитком ембріонів in vitro дозволило виявити, що стадії бластоцисти досягло $20,0,38,5$ та $56,9 \%$ ембріонів груп 1-3 відповідно.

Відомо, що кріоконсервування повинно забезпечувати збереження морфофункціональних властивостей біооб'єктів. Однією $з$ особливостей будови МII ооцитів $є$ наявність мейотичного веретена, мікротрубочки якого дуже чутливі до температурних коливань, що може спричинити порушення сегрегації хромосом та, як наслідок, анеуплоїдний набір хромосом. У зв'язку з цим кріоконсервування ооцитів на більш ранніх стадіях розвитку має перевагу. Показано, що кріоконсервування зрілих ооцитів не призводить до збільшення загального рівня хромосомних анеуплоїдій у ембріонів, але викликає певні зміни окремих хромосом [4].

\section{Results and discussion}

After cryopreservation, the survival rates for groups $1-3$ were $97.6,96.2$ and $98.2 \%$, respectively (Table). Oocytes of groups 1 and 2 had qualitative morphological characetristics, i. e. homogeneous and transparent cytoplasm, integral Zona pellucida $(Z P)$. However, the maturation rate in oocytes of group 1 was significantly lower as compared with those from group 2 and made 52.0 and $73.2 \%$, respectively.

The group 3 displayed the highest fertilization rate, and the lowest one was in group 2. Further embryo development in vitro enabled revealing $20.0,38.5$ and $56.9 \%$ of embryos of groups $1-3$, respectively, that survived to the blastocyst stage.

It is known that cryopreservation should ensure the preservation of morphological and functional properties of bioobjects. Among the features of MII oocyte structure is the presence of meiotic spindle, the microtubules of which are very sensitive to temperature fluctuations, likely resulting in a disorder of chromosome segregation and consequently in chromosomal aneuploidy. Proceeding from this fact, the cryopreservation of oocytes at earlier developmental stages is advantageous. Cryopreservation of mature oocytes showed no increase in total level of chromosomal aneuploidy in embryos, but caused certain changes in single chromosomes [3].

The first healthy live birth after vitrification of in vitro matured oocyte was reported in 2009 [4]. Since then, numerous studies, dealing with the efficient techniques for immature oocyte cryopreservation and the possibility of their in vitro maturation to preserve morphological and functional indices,
Виживаність, частота дозрівання, запліднення та бластуляція кріоконсервованих ооцитів залежно від способу та часу дозрівання

Survival, maturation, fertilization and blastulation rates of cryopreserved oocytes depending on way and time of maturation

\begin{tabular}{c|c|c|c|c}
\hline \multirow{2}{*}{$\begin{array}{c}\text { Група } \\
\text { Group }\end{array}$} & \multirow{2}{*}{$\begin{array}{c}\text { Виживаність, } \\
\text { Survival, \% }\end{array}$} & \multicolumn{3}{|c}{$\begin{array}{c}\text { Частота, } \\
\text { Rates, \% }\end{array}$} \\
\cline { 3 - 5 } & & $\begin{array}{c}\text { дозрівання } \\
\text { of maturation }\end{array}$ & $\begin{array}{c}\text { 3апліднення } \\
\text { of fertilization }\end{array}$ & $\begin{array}{c}\text { бластуляції } \\
\text { of blastulation }\end{array}$ \\
\hline 1 & 97,6 & 52,0 & 38,7 & 20,0 \\
\hline 2 & 96,2 & $73,2 *$ & $77,5^{*}$ & $38,5^{*}$ \\
\hline \multirow{2}{*}{3} & 98,2 & - & $89,5^{*}$ & $56,9^{*}$ \\
\hline
\end{tabular}

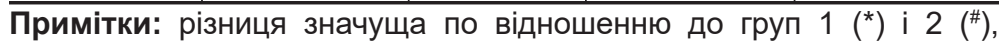
$p<0,05$.

Notes: difference is significant with respect to group $1\left(^{*}\right)$ and $2\left({ }^{\#}\right)$, $p<0.05$. 
Перше повідомлення про народження дитини після вітрифікації ооцита, дозрівання якого відбулося in vitro, 3'явилося у 2009 р. [5]. 3 того часу велика кількість наукових публікацій присвячена вивченню ефективності методів кріоконсервування незрілих ооцитів і можливості ix дозрівання in vitro для збереження морфофункціональних показників. У цьому аспекті важливе вивчення фізичних параметрів клітини, зокрема, іiі тургору, який може бути предиктором подальшого успішного запліднення та розвитку ембріона in vitro до стадії бластоцисти. Вважається, що цей параметр є дуже важливим для розробки ефективних методів кріоконсервування [1].

Деякі автори стверджують, що у кріоконсервованих шляхом вітрифікації ооцитів частота дозрівання, показники життєздатності, стан ZP та характеристики мейотичного веретена нижчі порівняно зі свіжовиділеними ооцитами на стадії GV [12]. Крім того, у деяких дослідженнях зазначено, що кількість ооцитів на стадії МII була значно більшою під час дозрівання перед кріоконсервуванням шляхом вітрифікації порівняно 3 тими, які дозрівали після відігріву, що узгоджується 3 результатами наших досліджень $[3,22]$. Було показано, що за частотою дозрівання, функціональним станом мітохондрій, хроматину та морфофункціональними характеристиками мейотичного веретена ооцити на стадіях GV та MI, які були вітрифіковані після дозрівання in vitro, мали кращі показники порівняно $з$ попередньо дозрілими гаметами [10].

Цікавим виявилися результати дослідження $з$ протилежними ефектом: після вітрифікації GV ооцитів підвищується частота їх дозрівання до стадії MII, значуще частіше відбувається партеногенетична активація ооцитів із подальшими нормальними морфокінетичними характеристиками ембріонів [13]. Автори вказують, що цей позитивний результат пов'язаний із дією кріозахисних розчинів, оскільки відомо, що ДМСО викликає тимчасове збільшення вмісту внутрішньоклітинного $\mathrm{Ca}^{2+}$ у різних типах клітин [14], а високі концентрації ЕГ (10-40\%) в мишачих ооцитах [20]. Однак ефект ЕГ нижчий за той, що індукує ДМСО, який характеризується більш високою здатністю до проникнення в клітини [16]. Найбільшим депо $\mathrm{Ca}^{2+}$ вважають ендоплазматичний ретикулум, через який мітохондpiї опосередковано спричиняють концентраційні коливання іонів під час активації ооцитів [21]. Після дозрівання гамет від стадії GV до MII відбувається накопичення $\mathrm{Ca}^{2+}$ в ендоцитоплазматичному ретикулумі, що необхідно для здійс- have been largely reported. In this context, of importance are physical parameters of cell, particularly its turgor, which may be predictive for further successful in vitro fertilization and embryo development to blastocyst stage. One considers this parameter to be of great importance for developing efficient cryopreservation techniques [17].

Some authors claimed that the oocytes cryopreserved by vitrification showed lower maturation and viability rates, ZP state and meiotic spindle characteristics as compared with fresh GV ones [11]. In addition, certain studies displayed much higher number of MII oocytes during maturation prior to cryopreservation by vitrification as compared with those matured after warming, that was consistent with our findings [2, 22]. It was shown that in terms of maturation rate, functional state of mitochondria, chromatin and morphofunctional characteristics of meiotic spindle, the GV and MI oocytes, vitrified after in vitro maturation, had higher rates as compared with pre-mature gametes [9].

Of particular interest were the findings with an opposite effect, $i$. e. after vitrification of $\mathrm{GV}$ oocytes their maturation rate up to MII stage was increased, and a parthenogenetic activation of oocytes with subsequent normal morphokinetic embryo characteristics occurred more frequently [12]. The authors mentioned this positive result to be associated with the action of cryoprotective solutions, since DMSO was known to cause a temporary increase in intracellular $\mathrm{Ca}^{2+}$ content in different cell types [13], and high EG concentrations $(10-40 \%)$ induced it in mouse oocytes [20]. However, the EG effect was lower than the one induced by DMSO, characterized by a higher ability to penetrate into cells [15]. The endoplasmic reticulum is considered to be the largest $\mathrm{Ca}^{2+}$ depot, through which the mitochondria indirectly cause the fluctuations in ionic concentrations during oocyte activation [21]. After gamete maturation from GV to MII stage, the $\mathrm{Ca}^{2+}$ is accumulated in endocytoplasmic reticulum, which is necessary for ion concentration fluctuations during fertilization $[1,7]$. Therefore, a premature induction of $\mathrm{Ca}^{2+}$ concentration changes in immature oocytes may entail premature oocyte activation, thus making impossible its further fertilization.

It has been shown that vitrified MI oocytes are able to reach the MII stage after warming under the standard medium, in contrast to the GV ones. This feature may be due to the oocyte susceptibility at GV stage, when a meiotic restitution occurs, to cryopreservation factors, in contrast to the ones at more advanced stage of MI development [6]. 
нення концентраційних коливань іонів під час запліднення [2, 8]. Тому передчасний виклик концентраційних змін $\mathrm{Ca}^{2+}$ в незрілих ооцитах може спричинити передчасну активацію ооциту, що унеможливлює його подальше запліднення.

Показано, що вітрифіковані МI ооцити здатні досягти стадії MII після відігріву в стандартному середовищі, на відміну від ооцитів стадії GV. Ця особливість може бути пов'язана з чутливістю ооцитів на стадії GV, коли відбувається відновлення мейозу, до дії факторів кріоконсервування на відміну від ооцитів, які знаходяться на більш просунутій стадії розвитку МI [7].

Результати проведеного дослідження показали відсутність негативного впливу кріоконсервування шляхом вітрифікації на виживаність зрілих і незрілих ооцитів. Проте частота дозрівання, запліднення та бластуляції була значуще вищою у ооцитах, які дозрівали від стадії GV до MII перед кріоконсервуванням, порівняно з вітрифікованими на стадії GV, проте нижчою порівняно 3 ооцитами, дозрівання яких відбувалося in vivo.

Отже, нами встановлено, що показники запліднення та розвитку ембріонів in vivo зрілих $\mathrm{GV}$ ооцитів вищі, ніж дозрілих in vitro, тому перспективною є розробка методичних та методологічних підходів їх дозрівання, що необхідно для збереження репродуктивної функції жінок.

\section{Висновки}

1. Виживаність ооцитів, кріоконсервованих методом вітрифікації, не залежить від ступеня їх зрілості.

2. Встановлено, що IVM ооцитів на стадії GV доцільно проводити перед кріоконсервуванням, що дозволяє отримати більш високі показники частоти дозрівання, запліднення та розвитку ембріонів in vitro.

Авторка висловлює подяку за натхнення, підтримку та консультативну допомогу з питань написання статті завідувачиі відділу кріобіологіi системи репродукиіі Інституту проблем кріобіологї і кріомедицини НАН Украӥни д.б.н., ст.н.с. Петрушко Марині Павлівні.

\section{Література}

1. Петрушко МП, Юрчук ТА, Будерацкая НА, и др. Инвагинация оолеммы в нативных и криоконсервированных ооцитах человека при их оплодотворении in vitro методом ICSI. Проблеми кріобіології кріомедицини 2018; 28 (3): 258-65.

2. Ajduk A, Małagocki A, Maleszewski M. Cytoplasmic maturation of mammalian oocytes: development of a mechanism responsible for sperm-induced $\mathrm{Ca}^{2+}$ oscillations. Reprod Biol. 2008; 8 : 3-22.
Our findings demonstrated no negative impact of cryopreservation by vitrification on mature and immature oocyte survival. However, the maturation, fertilization and blastulation rates were significantly higher in oocytes, matured from GV to MII stage prior to cryopreservation, if compared with those vitrified at GV stage, but lower than in vivo matured ones.

Thus, the study showed that the rates of fertilization and in vivo embryo development of mature $\mathrm{GV}$ oocytes were higher than in vitro matured ones, therefore further investigations should be targeted on designing the methodical and methodological approaches of their maturation, needed for preservation of female reproductive function.

\section{Conclusions}

1. No dependence of the survival rate of oocytes cryopreserved by vitrification on their maturity degree has been revealed.

2. It was established that IVM procedure for GV oocytes should be performed prior to cryopreservation, since it enabled obtaining higher rates of maturation, fertilization and embryo development in vitro.

The author is grateful to Marina P. Petrushko, D. Sc. (biology), senior research fellow, Head of the Department of Cryobiology of Reproductive System of the Institute for Problems of Cryobiology and Cryomedicine of the NAS of Ukraine for the inspiration, support and advice on writing this article.

\section{References}

1. Ajduk A, Małagocki A, Maleszewski M. Cytoplasmic maturation of mammalian oocytes: development of a mechanism responsible for sperm-induced $\mathrm{Ca}^{2+}$ oscillations. Reprod Biol. 2008; 8:3-22.

2. Brambillasca F, Guglielmo MC, Coticchio $G$ et al. The current challenges to efficient immature oocyte cryopreservation. J Assist Reprod Genet. 2013; 30(12): 1531-9.

3. Buderatska N, Gontar J, llyin I, et al. Does human oocyte cryopreservation affect equally on embryo chromosome aneuploidy? Cryobiology. 2020; 93: 33-6.

4. Chian RC, Gilbert L, Huang JY, et al. Live birth after vitrification of in vitro matured human oocytes. Fertil Steril. 2009; 91: 3726.

5. Fasano G, Dechène J, Antonacci R, et al. Outcomes of immature oocytes collected from ovarian tissue for cryopreservation in adult and prepubertal patients. Reprod Biomed Online. 2017; 34(6): 575-82.

6. Fasano G, Demeestere I, Englert Y. In-vitro maturation of human oocytes: before or after vitrification? J Assist Reprod Genet. 2012; 29: 507-12. 
3. Brambillasca F, Guglielmo MC, Coticchio G, et al. The current challenges to efficient immature oocyte cryopreservation. J Assist Reprod Genet. 2013; 30(12): 1531-9

4. Buderatska N, Gontar J, Ilyin I, et al. Does human oocyt ecryopreservation affect equally on embryo chromosome aneuploidy? Cryobiology. 2020; 93: 33-6.

5. Chian RC, Gilbert L, Huang JY, et al. Live birth after vitrification of in vitro matured human oocytes. Fertil Steril. 2009; 91: 372-6.

6. Fasano $G$, Dechène $J$, Antonacci $R$, et al. Outcomes of immature oocytes collected from ovarian tissue for cryopreservation in adult and prepubertal patients. Reprod Biomed Online. 2017; 34(6): 575-82.

7. Fasano G, Demeestere I, Englert Y. In-vitro maturation of human oocytes: before or after vitrification? J Assist Reprod Genet. 2012; 29: 507-12.

8. Jones KT, Carroll J, Whittingham DG. Ionomycin, thapsigargin ryanodine, and sperm induced $\mathrm{Ca}^{2+}$ release increase during meiotic maturation of mouse oocytes. J Biol Chem. 1995; 270(12): 6671-7.

9. Kuwayama M, Vajta G, Kato O, et al. Highly efficient vitrification method for cryopreservation of human oocytes. Reprod Biomed Online. 2005; 11(3): 300-8.

10.Lee JA, Sekhon L, Grunfeld L, et al. In-vitro maturation of germinal vesicle and metaphase l eggs prior to cryopreservation optimizes reproductive potential in patients undergoing fertility preservation. Curr Opin Obstet Gynecol. 2014; 26(3): 168-73.

11. McLaughlin M, Albertini DF, Wallace WHB, et al. Metaphase II oocytes from human unilaminar follicles grown in a multi-step culture system. Mol Hum Reprod. 2018; 24(3): 135-42.

12. Mohsenzadeh $\mathrm{M}$, Tabibnejad $\mathrm{N}$, Vatanparast $\mathrm{M}$, et al. Vitrification has detrimental effects on maturation, viability, and subcellular quality of oocytes post IVM in cancerous women: an experimental study. Int J Reprod Biomed (Yazd). 2019; 17(3): 175-84.

13. Molina I, Gómez J, Balasch S, et al. Osmotic-shock produced by vitrification solutions improves immature human oocytes in vitro maturation. Reprod Biol Endocrinol [Internet]. 2016 May 11 [cited 2020 July 12]; 14(1): 27. Available from: https:// rbej.biomedcentral.com/articles/10.1186/s12958-016-01611 \#citeas

14.Morley $\mathrm{P}$, Whitfield JF. The differentiation inducer, dimethyl sulfoxide, transiently increases the intracellular calcium ion concentration in various cell types. J Cell Physiol. 1993; 156: 219-22.

15.Muñoz E, González N, Muñoz L, et al. Ovarian stimulation In patients with breast cancer. Ecancermedicalscience [Internet]. 2015 Feb 3 [cited 2020 July 07]; 9: 504. Available from: https:// ecancer.org/es/journal/article/504-ovarian-stimulation-inpatients-with-breast-cancer

16.Paynter S. A rational approach to oocyte cryopreservation Reprod Biomed Online. 2005; 10: 578-86.

17.Petrushko M, Yurchuk T, Piniaiev V, Buderatska N. Cryopreservation of incomplete compacted morulae and preliminary biopsy of excluded fragments. Zygote. 2019; 27(6): 386-91.

18. Rivas Leonel EC, Lucci CM, Amorim CA. Cryopreservation of human ovarian tissue: a review. Transfus Med Hemother. 2019; 46(3): 173-81.

19. Takae S, Suzuki N. Current state and future possibilities of ovarian tissue transplantation. Reprod Med Biol. 2019; 18(3): 217-24.

20. Takahashi T, Igarashi H, Doshida M, et al. Lower ingintra cellular and extracellular calcium contents prevents cytotoxic effects of ethyleneglycol based vitrifications olutioninun fertilized mouse oocytes. Mol Reprod Dev. 2004; 68: 250-8

21.Wang F, Yuan RY, Li L, et al. Mitochondrial regulation of $\left[\mathrm{Ca}^{2+}\right] \mathrm{i}$ oscillations during cell cycle resumption of the second meiosis of oocyte. Cell Cycle. 2018; 17(12): 1471-86.

22. Yazdanpanah F, Khalili MA, Eftekhar M, et al. The effect of vitrification on maturation and viability capacities of immature human oocytes. Arch Gynecol Obstet. 2013; 288: 439-44.
7. Jones KT, Carroll J, Whittingham DG. Ionomycin, thapsigargin, ryanodine, and sperm induced $\mathrm{Ca}^{2+}$ release increase during meiotic maturation of mouse oocytes. J Biol Chem. 1995; 270(12): 6671-7

8. Kuwayama M, Vajta $G$, Kato $O$, et al. Highly efficient vitrification method for cryopreservation of human oocytes. Reprod Biomed Online. 2005; 11(3): 300-8.

9. Lee JA, Sekhon L, Grunfeld L, et al. In-vitro maturation of germinal vesicle and metaphase I eggs prior to cryopreservation optimizes reproductive potential in patients undergoing fertility preservation. Curr Opin Obstet Gynecol. 2014; 26(3): 168-73.

10.McLaughlin M, Albertini DF, Wallace WHB, et al. Metaphase II oocytes from human unilaminar follicles grown in a multi-step culture system. Mol Hum Reprod. 2018; 24(3): 135-42.

11. Mohsenzadeh $M$, Tabibnejad $N$, Vatanparast $M$, et al. Vitrification has detrimental effects on maturation, viability, and subcellular quality of oocytes post IVM in cancerous women: an experimental study. Int J Reprod Biomed (Yazd). 2019; 17(3): 175-84.

12.Molina I, Gómez J, Balasch S, et al. Osmotic-shock produced by vitrification solutions improves immature human oocytes in vitro maturation. Reprod Biol Endocrinol [Internet]. 2016 May 11 [cited 2020 July 12]; 14(1): 27. Available from: https:// rbej.biomedcentral.com/articles/10.1186/s12958-016-01611\#citeas.

13. Morley $\mathrm{P}$, Whitfield JF. The differentiation inducer, dimethyl sulfoxide, transiently increases the intracellular calcium ion concentration in various cell types. J Cell Physiol. 1993; 156: 219-22.

14.Muñoz E, González N, Muñoz L, et al. Ovarian stimulation In patients with breast cancer. Ecancermedicalscience [Internet]. 2015 Feb 3 [cited 2020 July 07]; 9: 504. Available from: https:// ecancer.org/es/journal/article/504-ovarian-stimulation-inpatients-with-breast-cancer

15. Paynter S. A rational approach to oocyte cryopreservation. Reprod Biomed Online. 2005; 10: 578-86.

16.Petrushko MP, Yurchuk TO, Buderatska NO, et al. Oolemma invagination of fresh and cryopreserved human oocytes during in vitro fertilization by ICSI. Probl Cryobiol Cryomed. 2018; 28(3): 258-65.

17.Petrushko M, Yurchuk T, Piniaiev V, Buderatska N. Cryopreservation of incomplete compacted morulae and preliminary biopsy of excluded fragments. Zygote. 2019; 27(6): 386-91.

18. Rivas Leonel EC, Lucci CM, Amorim CA. Cryopreservation of human ovarian tissue: a review. Transfus Med Hemother. 2019; 46(3): 173-81

19. Takae S, Suzuki N. Current state and future possibilities of ovarian tissue transplantation. Reprod Med Biol. 2019; 18(3): 217-24

20. Takahashi $T$, Igarashi $H$, Doshida $M$, et al. Lower ingintra cellular and extracellular calcium contents prevents cytotoxic effects of ethyleneglycol based vitrifications olutioninun fertilized mouse oocytes. Mol Reprod Dev. 2004; 68: 250-8.

21.Wang F, Yuan RY, Li L, et al. Mitochondrial regulation of [Ca $\left.{ }^{2+}\right]$ i oscillations during cell cycle resumption of the second meiosis of oocyte. Cell Cycle. 2018; 17(12): 1471-86.

22. Yazdanpanah F, Khalili MA, Eftekhar M, et al. The effect of vitrification on maturation and viability capacities of immature human oocytes. Arch Gynecol Obstet 2013; 288: 43944. 